\title{
Prophylactic treatments of migraine and GPs in the north of France: evaluation of practices
}

\author{
CL Christian \\ From The European Headache and Migraine Trust International Congress \\ London, UK. 20-23 September 2012
}

\section{Introduction}

Prophylactic treatments of migraine are an important part of the management of the disease. Only one survey concerning this topic was performed in 2000 in France among GPs. This survey was however performed before the French migraine guidelines with a large use of dihydroergotamine at this time.

\section{Purpose}

To evaluate the practices of GPS in the North of France concerning the prophylactic treatments of migraine management and to compare them with the French Guidelines.

\section{Methods}

A self-administered questionnaire concerning prophylactic treatments of migraine was mailed in 2011 to 307 GPs in two big cities in the North of France (Lille and Roubaix). We analysed the data and compared them with the French Guidelines.

\section{Results}

142 GPs answered to the questionnaire (46.2 \%). $85 \%$ of GPs use prophylactic treatments of migraine when the patient has 4 to 5 migraine attacks per month. The first line treatment are beta-bloquers (BB) $(60 \%)$. The first objective is to reduce the migraine attacks frequency by $50 \%$ at 3 months for $53 \%$ of the GPs and the second to increase the quality of life in $45 \% .59 \%$ of GPs prescribe prophylactic treatment of migraine for a 6-12 months duration.

\section{Discussion}

GPS in the North of France take into account the bad quality of life of migrainers to start a prophylactic treatment. They use in majority the recommended prophylactic treatments of migraine and during a correct duration according the French Guidelines.

\section{Conclusion}

There is a dramatic increase since 2000 of the use of BB in France as first line prophylactic treatment of migraine. French guidelines of migraine seems to be useful for GPs.

Published: 21 February 2013

\section{References}

1. Lantéri-Minet M, Alchaar $H$, Besson $G$, et al: Etude pharmacoépidémiologique sur le traitement de fond de la migraine. Enquête nationale sur les attitudes de prescription des omni-praticiens et des neurologues français. Rev Neurol 2000, 156:1106-1112.

2. Geraud G, Lanteri-Minet M, Lucas C, Valade D: French guidelines for the diagnosis and management of migraine in adults and children. Clin Ther 2004, 26(8):1305-1318.

doi:10.1186/1129-2377-14-S1-P213

Cite this article as: Christian: Prophylactic treatments of migraine and GPs in the north of France: evaluation of practices. The Journal of Headache and Pain 2013 14(Suppl 1):P213.

Submit your manuscript to a SpringerOpen ${ }^{\circ}$ journal and benefit from:

- Convenient online submission

- Rigorous peer review

- Immediate publication on acceptance

- Open access: articles freely available online

- High visibility within the field

- Retaining the copyright to your article

Submit your next manuscript at $>$ springeropen.com 